\title{
Growth Cones of Regenerating Retinal Axons Contact a Variety of Cellular Profiles in the Transected Goldfish Optic Nerve
}

\author{
GABRIELLE STROBEL AND CLAUDIA A.O. STUERMER \\ Faculty of Biology, University of Konstanz, D-78434 Konstanz, Germany
}

\begin{abstract}
Following optic nerve transection in goldfish, retinal axons regenerate. To determine what the growth cones use as a substrate for their growth, regenerating growth cones were labeled by horseradish peroxidase (HRP) application to the retina 5-6 days after intraorbital optic nerve section (ONS) and identified at 10-11 days after ONS in the brain sided (distal) portion of the optic nerve in thick and serial ultrathin sections. Leading growth cones $(n=5)$ were found in intimate contact with a variety of elements: with myelin fragments alone, with myelin fragments and glial cells, and with the basal lamina of the glia limitans and the surface of a fibroblast outside the boundary of previous fascicles.

In ultrathin sections of conventionally treated regenerating optic nerves, (unlabeled) axon profiles - in addition to myelin fragments - were seen to be in contact with an astrocyte and an oligodendrocyte, suggesting that the growth cones of these axons may have been associated with those cells. The data suggest that leading growth cones of regenerating axons may be capable of growing along myelin fragments and on a wide variety of cellular surfaces in the goldfish optic nerve.
\end{abstract}

Key words: HRP-labeled growth cones, optic nerve injury, glial cells, myelin debris, potential substrates

Upon transection of the optic nerve in fish, axons of retinal ganglion cells regenerate and reinnervate their visual target center (Attardi and Sperry, 1963), whereas injured retinal axons in mammals fail to regrow (for review, see Skene, 1989). One reason for the failure of axonal regeneration in the mammalian central nervous system (CNS) lies in the unfavorable substrate properties of CNS glial cells. Oligodendrocytes and CNS myelin possess proteins that lead to growth cone collapse and to the inhibition of axonal elongation (Caroni and Schwab, 1988; Schwab and Caroni, 1988; Fawcett et al., 1989; Keirstead et al., 1992). Reactive astrocytes that form the so-called glial scar also interfere with axonal elongation (Liuzzi and Lasek, 1987; Bovolenta et al., 1991).

Such impediments for axonal regeneration are apparently absent from the fish optic nerve, where astrocytic scars do not develop (Wolburg and Kästner, 1984; Stafford et al., 1990). Biochemical analysis showed that fish oligodendrocytes and CNS myelin lack the proteins that inhibit axon growth in mammals (Caroni and Schwab, 1988). This was supported by in vitro studies (Bastmeyer et al., 1991, 1993). Retinal explants of fish extend axons on a substrate consisting of fish CNS myelin, but axon outgrowth fails on a substrate of CNS myelin from the rat (Bastmeyer et al., 1991). Likewise, rat retinal axons grow on fish oligodendrocytes in culture (Bastmeyer et al., 1993), but fish growth cones collapse when they encounter rat oligodendrocytes (Bastmeyer et al., 1991).

The present study was undertaken to compare the in vitro results to the situation in vivo. The method of choice is to visualize the elements with which the surface of the growth cone is closely associated (Scherer and Easter, 1984; Easter, 1987). This requires ultrastructural identification of the growth cone and the elements that it contacts. Applied to the developing nervous system, this method has revealed the substrates of the first growth cones that pioneer specific pathways in a variety of species (for review, see Letourneau et al., 1991). Later-arriving axons in these pathways most commonly fasciculate with these pioneers and thus use existing axonal surfaces as the substrate for their growth.

\footnotetext{
Accepted February 26, 1994

Address reprint requests to Claudia A.O. Stuermer, Faculty of Biology, University of Konstanz, D-78434 Konstanz, Germany
} 
The favored substrate of growth cones in most parts of the fish visual pathway is young axons (Easter et al., 1981, 1984; Easter, 1987). However, where preceding axons are out of reach or are not present, retinal growth cones must choose other substrates. Growth cones of newly formed ganglion cells in the periphery of the continuously growing fish retina were found to touch the basal lamina that separates the neural retina from the vitreous (Easter et al., 1984). Farther from their cells of origin, growth cones continue to advance along older axons within the retina in the optic nerve and the optic tract and into the tectum. The fish optic nerve is divided into fascicles, each of which is surrounded by astrocytic processes and basal lamina, forming the glia limitans (Maggs and Scholes, 1990). Whether regenerating retinal axons after nerve injury use basal lamina as their preferred substrate was examined by Easter (1987). He found a small group of regenerating axons growing along each other in the middle of fascicles but did not report on the leading growth cone of this group. Thus, the substrates used by the first and leading regenerating axons in a previously lesioned nerve remained to be identified. It has repeatedly been suggested that fish retinal growth cone might be guided by astrocytes during regeneration, but direct evidence is not available (Murray, 1976; Wolburg et al., 1986).

In this study, we first tried to obtain an impression of the cellular composition of the optic nerve under normal conditions and after lesion. Ultrathin sections were examined to identify the various glial cells by their ultrastructural characteristics (Wolburg et al., 1986; Maggs and Scholes, 1990; Peters et al., 1991). The regenerating growth cones were, among the various elements of the lesioned optic nerve, labeled by intraretinal application of horseradish peroxidase (HRP; Stuermer, 1988a,b), and the cellular elements with which they were in contact were identified.

Growth cones were in intimate contact with a variety of elements and cells of the regenerating optic nerve, including myelin fragments. Our observations suggest that regenerating growth cones are capable of associating with a variety of surfaces in the injured optic nerve. These data were previously presented in abstract form (Strobel and Stuermer, 1991).

\section{MATERIALS AND METHODS}

The optic nerves of goldfish $(5-7 \mathrm{~cm}$ long from mouth to tail fin tip) were cut intraorbitally (midway between the eye and the entrance of the optic nerve into the skull) under MS 222 (Sandoz) anesthesia. To label the regenerating axons, 5-6 days after intraorbital optic nerve section (ONS), compressed crystals of HRP (Miles) were picked up with a fine needle and applied intraretinally by inserting the HRP-covered tip of the needle into the retinal axon layer close to the optic disk in each retinal sector (Stuermer, 1988a,b). Four to five days after HRP application, the optic nerves were excised and transferred into fixative. The procedure for HRP labeling of growth cones was described earlier and includes applying HRP to axons by rupturing them intraretinally (Stuermer, 1988a,b), with the danger that the growth cones degenerate. The appearance of the HRP-labeled growth cones in whole mounts (Stuermer, $1988 \mathrm{~b}$ ), in thick, semithin and ultrathin sections, indicates that they do not undergo severe degenerational changes within the 3 days between HRP application and fixation. They possessed filopodia and their typical tubular and vesicular internal structures. Not all regenerating axons were labeled by this procedure. We observed HRP-labeled growth cones that were obviously growing along forerunning unlabeled axons. Four of the five preparations presented in the Results were immersed in a $4^{\circ} \mathrm{C}$ solution consisting of $4 \%$ glutaraldehyde, $7.5 \%$ sucrose, $1 \mathrm{mM} \mathrm{CaCl}_{2}$ in $50 \mathrm{mM}$ cacodylate buffer ( $\mathrm{pH} 7.2$ ) for 4 hours at $4^{\circ} \mathrm{C}$ They were then rinsed three times for 15 minutes each in buffer ( $1 \mathrm{mM} \mathrm{CaCl}_{2}$ in $100 \mathrm{mM}$ cacodylate buffer, $\left.\mathrm{pH} 7.2\right)$ at room temperature (Easter et al., 1984). Better ultrastructural preservation was achieved in an alternate preparation (growth cone 5 in Results) by fixation in $1 \%$ glutaraldehyde in $150 \mathrm{mM}$ cacodylate buffer ( $\mathrm{pH} 7.2$ ) without sucrose or $\mathrm{CaCl}_{2}$ for 30 minutes at room temperature and rinsing three times for 10 minutes each in $150 \mathrm{mM}$ cacodylate buffer (according to John Scholes, personal communication). The nerves were divided longitudinally into $100-150$ $\mu \mathrm{m}$ thick slices either with a razor blade or after embedding them in $2 \%$ agarose and cutting them on a tissue chopper (McIlwain).

The sections were incubated in $1 \mathrm{mg} / \mathrm{ml}$ diaminobenzidine (DAB; Sigma, St. Louis, MO) solution in $100 \mathrm{mM}$ cacodylate buffer ( $\mathrm{pH}$ 6). After 10 minutes, hydrogen peroxide $(0.03 \%$ final concentration) was added to the solution, and, after 1 hour, the sections were transferred into buffer. The treatment of the tissue for visualization of the HRP reaction product negatively affected the ultrastructure of the tissue. For light microscopic examination, the sections were first dehydrated in a series of ethanols, cleared in xylene, and coverslipped under Euparal (Roth).

For electron microscopy, the sections were placed on a slide in buffer, protected by a coverslip, and examined in the microscope with Nomarski (DIC) optics for the presence of HRP-labeled axons and growth cones. Recognition of HRPlabeled growth cones among other dense profiles, such as myelin fragments, necessitated the omission of osmium tetroxide for postfixation in most cases and also prohibited counterstaining of the sections. However, selected sections were postfixed in $1 \%$ osmium tetroxide (Science Services) in double distilled water for 2 hours at room temperature and rinsed in double distilled water. All sections were dehydrated in a graded series of ethanols (20 minutes each in $30 \%, 50 \%$, and $70 \%$, twice for 20 minutes each in $95 \%$, and three times in $100 \%$ ethanols).

The sections, sandwiched between transparent film conventionally used for photocopies, were flat embedded in a drop of Epon on glass slides. Polymerization was at $60^{\circ} \mathrm{C}$ for 48 hours. After removal of the slide and the foil covering the section, a drop of unpolymerized Epon was added, and polymerized Epon in a Beem capsule was placed on top. After another 48 hours at $60^{\circ} \mathrm{C}$, the sections with the Epon capsule were removed from the slide and foil, ready for sectioning. Serial sections $2-5 \mu \mathrm{m}$ thick were placed on polylysine-coated coverslips and examined with Nomarski optics. HRP-labeled axons and growth cones were photographed. Sections with growth cones received a drop of a Mikropal polyester resin mixture (Ferrak) and remained for 12 hours at $60^{\circ} \mathrm{C}$ for polymerization. Then, a Mikropalfilled Beem capsule was placed on top and polymerized for 24 hours at $60^{\circ} \mathrm{C}$. Separation of the coverslip from the section was achieved on dry ice. The photomicrographs of the semithin section were used to determine the approximate localization of the growth cone of interest in the preparation. After trimming, the preparation was serially sectioned on the ultramicrotome. In most cases (growth 
cones 1-4), ultrathin sections were observed in the electron microscope (Philips EM 10 or Zeiss EM 900) at $60 \mathrm{kV}$ without counterstaining and micrographed. Sections from preparations in which the growth cones were heavily labeled by the HRP reaction product (growth cone 5) were counterstained with uranyl acetate and lead citrate (Venable and Coggeshall, 1965) and micrographed in the electron microscope at $80 \mathrm{kV}$. For structural comparison, normal and regenerating optic nerves (9-14 days after ONS) that had not undergone the histochemical treatment for HRP visualization were fixed in $1 \%$ glutaraldehyde in

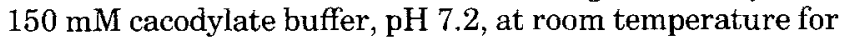
30 minutes. After a rinse in the above-described buffer, they were postfixed in $1 \% \mathrm{OsO}_{4}$ in the same buffer for 3-5 hours and washed three times for 15 minutes each in double distilled water. They were dehydrated in ethanol $(50 \%$, $70 \%$, and $100 \%$; three times for 10 minutes each) and propylene oxide ( 15 minutes). They were first transferred into a mixture (3:1) of propylene oxide/Durcupan (Fluka) for 10 minutes and then into $100 \%$ Durcupan for 5 minutes. Polymerization of the flat-embedded specimen was at $70^{\circ} \mathrm{C}$ overnight. Cross sections $(700 \times 700 \mu \mathrm{m})$ of the entire optic nerve were picked up on uncoated slot grids and in a drop of water lowered onto a Pioloform-coated special template. Evaporation of the water led to an attachment of the grid and the section to the film [0.5\% Pioloform (Wacker, Burghausen) in diclorethan (Merck, Darmstadt)], and grid and Piolofilm were excised. This method allows very large sections to be picked up free of folds. Sections were counterstained according to Venable and Coggeshall (1965) with lead citrate and uranyl acetate and micrographed in the EM at $60-100 \mathrm{kV}$. The various glial cell types of the optic nerve were identified by their specific characteristics described in the literature cited in the Results section.

\section{Reconstruction of ultrathin serial sections}

The three-dimensional reconstruction of individual growth cones and the elements in their vicinity was performed with the aid of the computer program Histol (List-electronic; Hengstenberg et al., 1983), which was kindly provided and explained to us by $R$. Hengstenberg (Tübingen).

EM negatives of individual sections were projected and drawn on a transparency. Selected structures served as landmarks for the orientation of the profiles in consecutive negatives. With the data acquisition program HSDIG and a digitizing tablet (Kontron), the transparencies were coded and read into a computer (IBM PC-X'T 386). Parameters such as thickness of the section, calibration, codings for the identification of specific profiles, and increments of resolution were specified in the data files. To obtain the best orientations for the representation of their spatial relationship, the reconstructed profiles were tilted in various angles around imaginary $x, y, z$ axes. Pseudo-three-dimensional plots (hidden-line plots) were printed on a Hewlett Packard 7574 plotter.

\section{RESULTS}

Following intraorbital ONS, the lesioned axons form growth cones at the proximal axon stumps (Lanners and Grafstein, 1980; "proximal" meaning here the portion of the nerve that remains connected to the eye). In the fish used here, growth cones of regenerating axons arrived at the level of the chiasm by roughly 9 days and, at the tectum, by 10-12 days after ONS. In this study, the portion of the nerve $300-400 \mu \mathrm{m}$ proximal to the chiasm was examined at 9-10 days after ONS for HRP-labeled growth cones and at 9-14 days after ONS for glial cells in ultrathin sections of conventionally treated nerves. The retinae of these nerves had not received HRP, nor had they been exposed to the reagents required later to visualize the HRP.

\section{Glial cells of the regenerating optic nerve}

In sectioned nerves, the glia limitans and the basal lamina, which normally surround the axon fascicles (Maggs and Scholes, 1990) and are formed by astrocytes, remained intact (Fig. 1a). Astrocytic processes that further partitioned these fascicles were noted among the degenerating axons. The sectioned fascicles exhibited extracellular spaces (Easter, 1987; Fig. 1a), myelin debris of degenerated axons, and glial cells, which appeared to be more numerous than in the normal fascicles. Astrocytes and their processes typically contained numerous strands of glial filaments, pale nuclei, and desmosomes with neighboring astrocytic processes (Fig. 1; Maggs and Scholes, 1990). They were most numerous at the margins of the old fascicles (Figs. 1a, 8). Some astrocytes (Fig. 1b) may represent the "reactive astrocytes" of Wolburg and Kästner (1984). They are particularly rich in organelles and have a large cytoplasmic area with respect to the nucleus.

Consistent with the report of Mori and Leblond (1970) on the developing rat corpus callosum, there were classes of oligodendrocytes that ranged in nuclear and cytoplasmic electron density from dark to light and varied in perinuclear cytoplasmic area and in the prevalence of organelles. Medium dark oligodendrocytes resemble those seen during Wallerian degeneration in the rat optic nerve (Vaughn and Pease, 1970) and fish oligodendrocytes in vitro (Bastmeyer et al., 1993; Fig. 1a). These may represent what we term "reactive" oligodendrocytes, perhaps evolving by dedifferentiation of small dark oligodendrocytes or deriving from light oligodendrocyte precursors (Vaughn and Pease, 1970). Oligodendrocytes with light nuclei and cytoplasm, the presumed precursors (Scholes, personal communication), are particularly rich in free ribosomes and ribosome rosettes and contain few mitochondria but few other cell organelles (Vaughn and Pease, 1970).

Microglial cells were identified by their individual long and "stringy" rER cisternae (Fulcrand and Privat, 1977; Peters et al., 1991), nuclei with heterochromatin and numerous indentations, and various granules and lysosomes. Regions between and outside the nerve fascicles (but not within the fascicles themselves) contained cells resembling fibroblasts with electron-lucent cytoplasm and nucleus. They contained stacks of rER and thin cytoplasmic processes. Collagen fibrils were present in their vicinity. That cells of this type may represent fibroblasts or at least fibroblast-like cells is supported by a recent study demonstrating antifibronectin immunoreactivity associated with cells in interfascicular areas and with such cells in culture (Hirsch et al., in press). The regions outside the previous fascicles also contained granulocytes. Granulocytes of the hematopoietic cell lines were readily recognized by their numerous and prominent granula (Rhodin, 1977).

\section{Regenerating growth cones}

Growth cones of regenerating axons loaded with HRP reaction product were readily identified in the 100-150- $\mu \mathrm{m}$ thick slices, in semithin sections (Fig. 2), and in ultrathin 

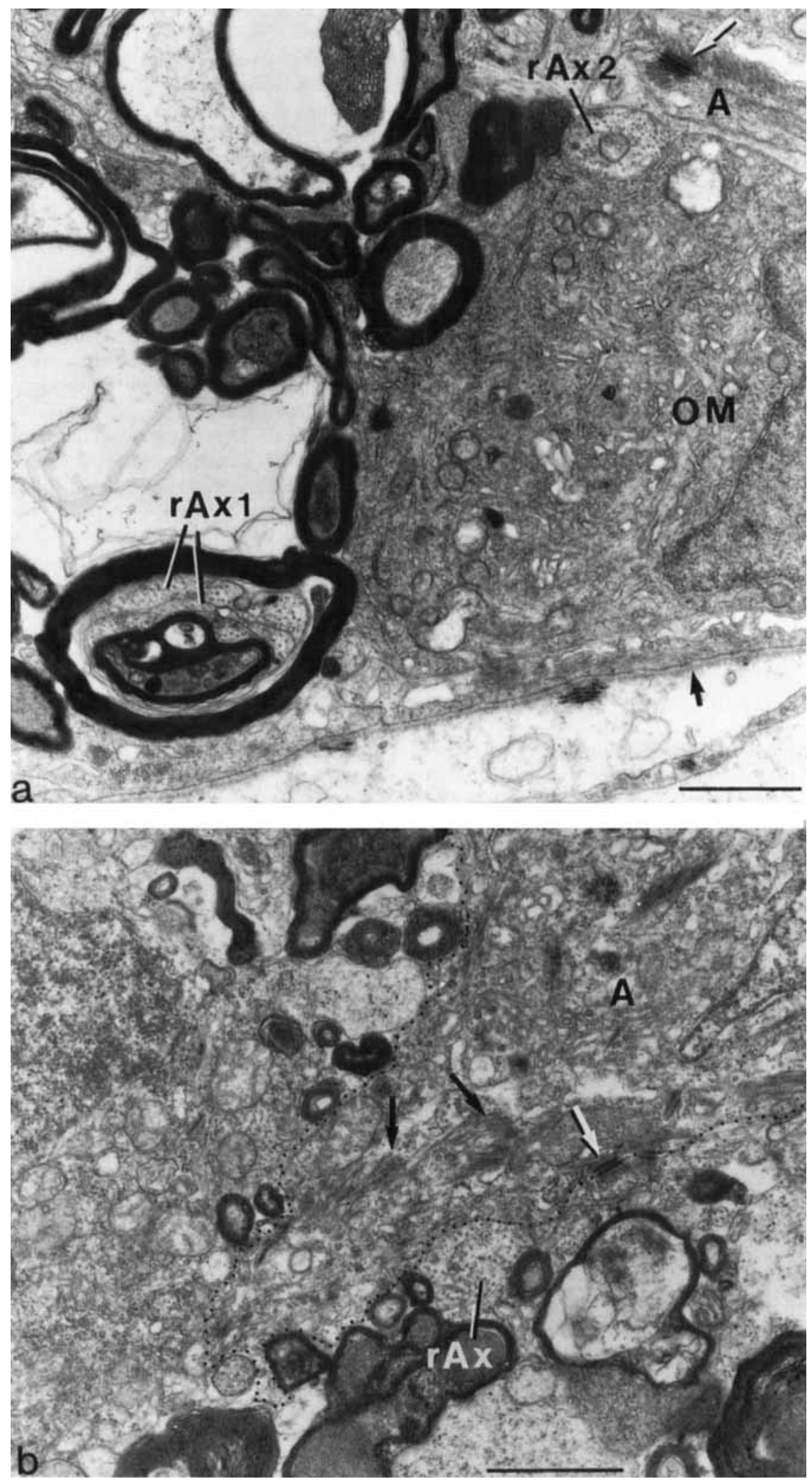

Fig. 1. Ultrathin sections of an optic nerve, 11 days after optic nerve section (ONS), processed according to conventional electron microscopic protocol. a: Organelle-rich cytoplasm of a medium dark (OM; "reactive") oligodendrocyte. Black arrow points to the basal lamina of the glia limitans formed by astrocytic processes. White arrow marks a desmosume between processes of astrocytes (A) which are rich in fibrils. To the left of the oligodendrocyte are extracellular spaces, myelin tubes and debris (black) from degenerating myelinated axons. Profiles of regenerating axons ( $\mathrm{rAx} 1)$ can be seen within a degenerating myelin tube, and another profile ( $\mathrm{rAx} 2)$ is in contact with the oligodendrocyte, the astrocyte processes, and debris. b: Cytoplasm of a "reactive" astrocyte (A), which is identified by clusters of fibrils (black arrows) and desmosomes (white arrow). The cell's border is indicated by a dotted line. Dark myelin of degenerating axons is seen between the processes of cells. The cross sectioned profile of a regenerating axon $(\mathrm{rAx})$ is in close contact with the astrocyte. Scale bars $=1 \mu \mathrm{m}$. 


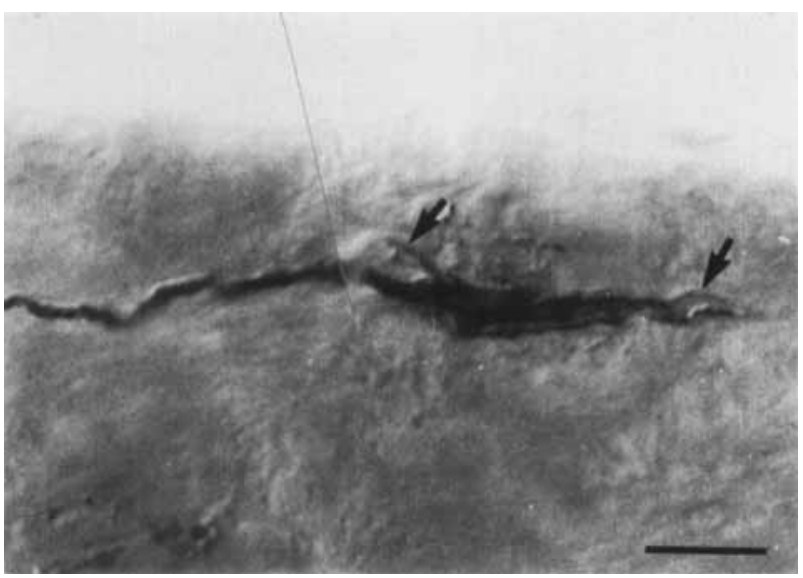

Fig. 2. HRP-labeled leading growth cone in an optic nerve 9 days after ONS, identified in a $100-\mu \mathrm{m}$-thick section and photographed with Nomarski optics. Note its filopodia (arrows). Scale bar $=5 \mu \mathrm{m}$.

sections (Figs. 3-6). Only those growth cones that appeared singly, and thus most likely represented leading growth cones, were selected for further examination. Of the 10 selected growth cones that were serially sectioned, five were, at least in part, closely associated with unmyelinated profiles that appeared to be unlabeled axons with electronlucent cytoplasm, microtubuli, and neurofilaments (Easter et al., 1984; Easter, 1987; see also Fig. 1). The remaining five were regarded as leading growth cones because they were found to contact various nonaxonal elements of the nerve.

Growth cone 1. The growth cone shown in Figure 3 was reconstructed from 40 serial ultrathin sections. Surprisingly, this growth cone was in membrane-to-membrane contact with myelin fragments over a substantial portion of its surface. It was also in contact with a cell process. The identification of this process was hampered by the insufficient ultrastructural preservation of the tissue. In neighboring cells, bundles of filaments and desmosomes were recognized, which characterized them as astrocytes. In that these features were absent from the glial process touched by the growth cone, it may be an oligodendrocyte or a microglial cell. Growth cone contact with myelin was confirmed in three other samples (growth cones 2-4).

Growth cones 2 and 3. Extensive association with presumptive myelin fragments was observed for the growth cone in Figure 4, which was sectioned parallel to its long axis. In fact, this growth cone appeared to run almost exclusively between and on one side of the presumptive myelin fragments. No other glial cells or glial processes were seen in its immediate vicinity. There were, however, extracellular spaces mostly opposite to its association with the myelin fragments. Whether these spaces contain extracellular matrix proteins that promote axonal growth is not known. The HRP-labeled profile in Figure 4 represents most but not all of the elongated growth cone's extent. Its distal tip, which continues another $3 \mu \mathrm{m}$ to the right of the profile in Figure 4, was seen in the thick sections but broke off during the reembedding. That the segment seen here is indeed part of the growth cone proper is shown by its content of numerous, variably sized vesicles and electronlucent tubular structures typical of growth cones (Scherer and Easter, 1984).
Another axon, whose distalmost tip ( $3 \mu \mathrm{m}$ long) was lost, is shown in Figure 5. An 11- $\mu$ m-long portion of the axon and growth cone was followed over 15 serial ultrathin sections and was seen in contact with, and sometimes between, myelin fragments. Although its farthest tip is missing, the arrangement of the profiles suggests that the growth cone had moved along myelin debris.

Growth cone 4. This growth cone (Fig. 6a,b) was followed through 36 serial ultrathin sections and documented in representative drawings (Fig. 7). Growth cone 4 was located between a glial cell and a large fragment of myelin. The surface of the growth cone and the myelin fragment were very close together in the distal half of the growth cone's extent and in patches in the growth cone's more proximal part.

The growth cone's surface was also in close association with the surface membrane of the glial cell throughout its extent (Figs. 6a,b, 7). Despite the poor preservation of the cytoplasm, some cellular characteristics were revealed in screening the serial sections with particular care. The glial cell exhibited a medium-darkness rather than dark cytoplasm and contained small electron-dense mitochondria (Fig. 6a,b). The eccentric nucleus was indented and contained patches of condensed chromatin that were largely accumulated at the nuclear margin. Microtubuli were also present throughout the cell. Strands of glial filaments, or desmosomes, clearly recognized in nearby astrocytes of the same sections were not noted for this cell. This cell resembled medium oligodendrocytes (Fig. 1a) and fish oligodendrocytes in culture (Bastmeyer et al., 1993). It also matches the description of interfascicular oligodendrocytes (Peters et al., 1991) and may belong to the category of "reactive" (Vaughn and Pease, 1970), medium dark oligodendrocytes (Mori and Leblond, 1970). Light and mediumdarkness oligodendrocytes are often difficult to distinguish from microglial cells (Peters et al., 1991). However, the glial cell shown in Figure 6 did not contain the "stringy" ER (Maggs and Scholes, 1990; Peters et al., 1991) typical of microglial cells and had mitochondria similar to those seen in Figure 1a and similar to those in fish oligodendrocytes in vitro (Bastmeyer et al., 1993). These differed from the larger and lighter mitochondria with distinct cristae found in microglial cells.

Growth cone 5. The fifth growth cone (Figs. 8, 9) was traced over 98 serial sections. It was found in a preparation that had been treated according to the improved fixation protocol (Materials and Methods). The intensity of the HRP reaction product allowed counterstaining of the sections. The growth cone was bifurcated and located outside the boundaries of previous fascicles, where a large number of granulocytes was also present. One branch of the growth cone contacted the basal lamina of adjacent astrocytes that bound one of the fascicles (Figs. 8, 9). The other branch, almost at a right angle to the first one, was in contact with a process of a cell that we consider as a fibroblast or fibroblastlike cell (Figs. 8, 9). The fibroblast-like cell was identified by its typical ER (Peters et al., 1991). Collagen fibrils were seen in the vicinity of this cell in some but not all of the serial sections as well as in association with cells of similar ultrastructural appearance in interfascicular areas of other nerve preparations. The fibroblast process itself ran close to the basal lamina of astrocytes that formed a boundary around another previous fascicle. Taken together, observations made on these five growth cones suggest that leading 

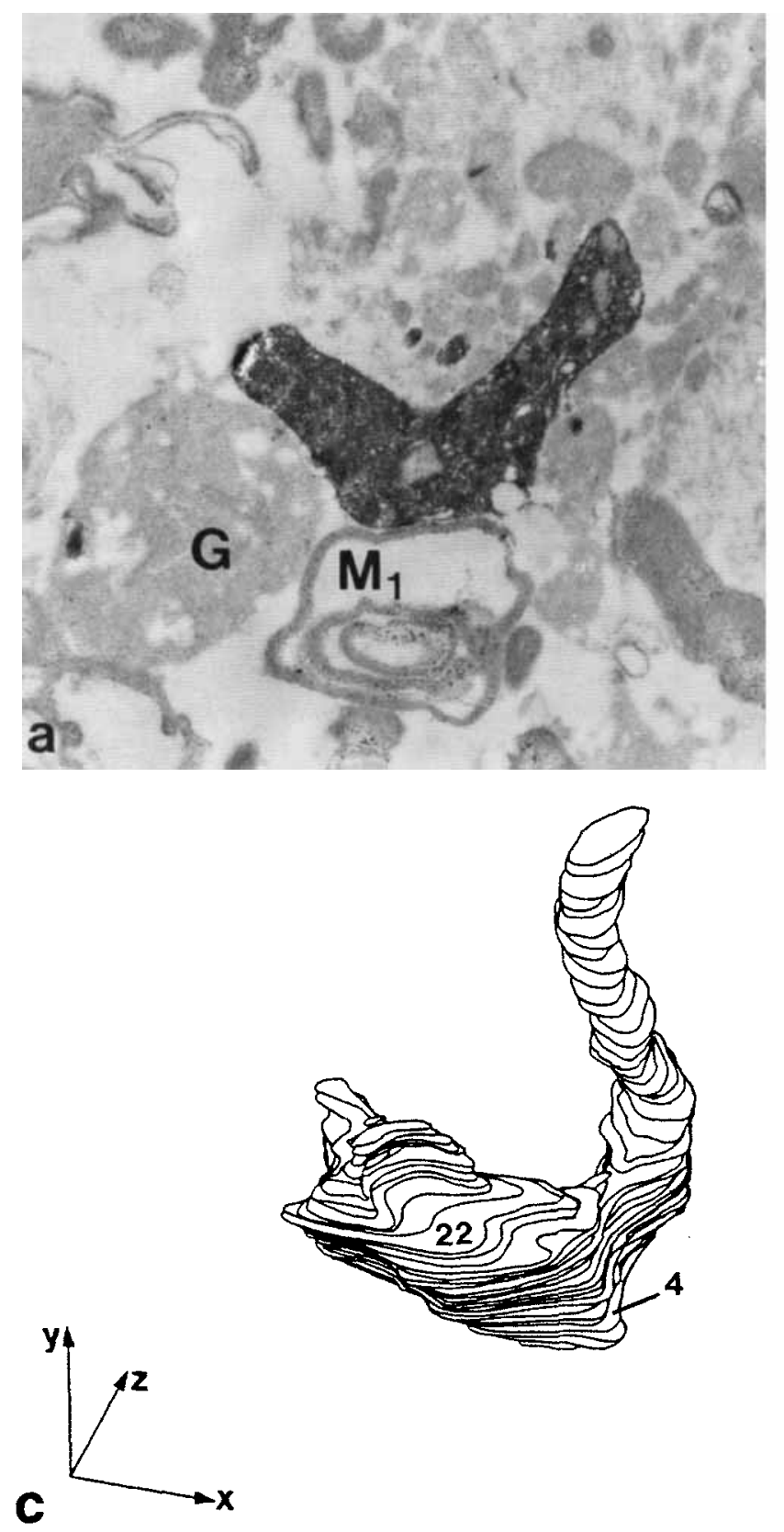

Fig 3. Electron micrographs $(a, b)$ and computer reconstructions (c,d) of an HRP-labeled growth cone. a: Section number 4, showing the association of the growth cone with a myelin fragment (M1) and a cell process $(\mathrm{G})$. b: Section 22 showing the same growth cone in contact with another myelin fragment (M2). The axon from which the growth cone stems (Ax) is seen at the right. c: Reconstruction of the growth

growth cones of regenerating retinal axons associate with a variety of cells and profiles within the optic nerve.

\section{Location of regenerating axonal profiles}

Observations on the locations of axons in sections through regenerating optic nerves, which had not undergone the HRP-labeling procedure (Fig. 1a,b), are in agreement with this conclusion. Figure la shows a cross section of an axon
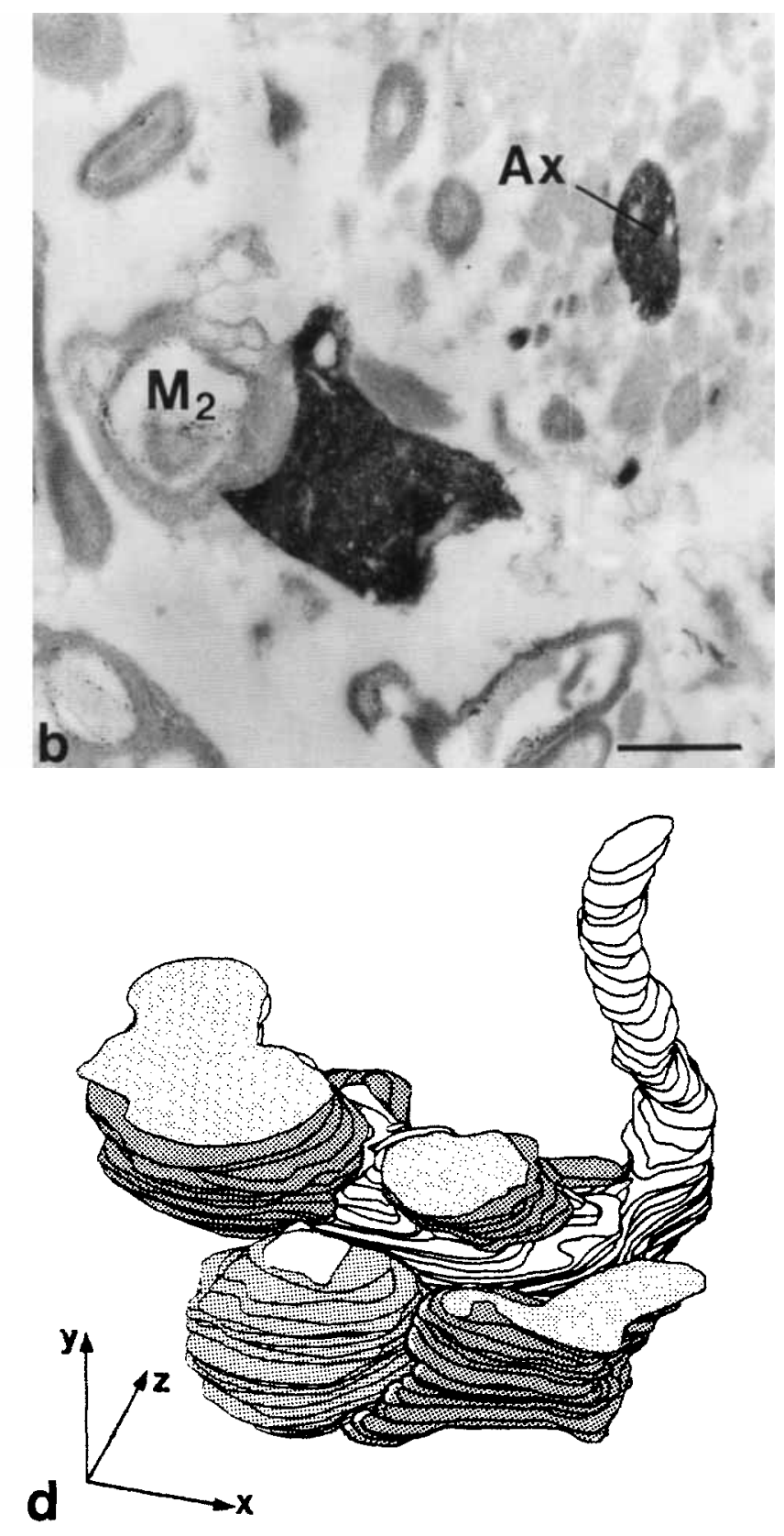

cone alone. The sections shown in a and $\mathrm{b}$ are indicated $(4$ and 22 , respectively). d: Reconstruction of the growth cone, axon, and the cell process (light shading) and myelin fragments (dark shading) that were seen in contact with it. The $x, y, z$ axes are indicated. Scale bar $=1 \mu \mathrm{m}$ for $a$ and $b$.

identified by its electron-lucent axoplasm and its content of microtubuli and neurofilaments (Easter et al., 1984; Easter, 1987). It is in direct contact with an oligodendrocyte, an astrocytic process, and decaying myelin. Although we did not see the growth cone, the location of this axon suggests that its growth cone passed among the same profiles. A group of three axon profiles was noted in the same section (Fig. 1a) within the boundaries of a myelin fragment that 


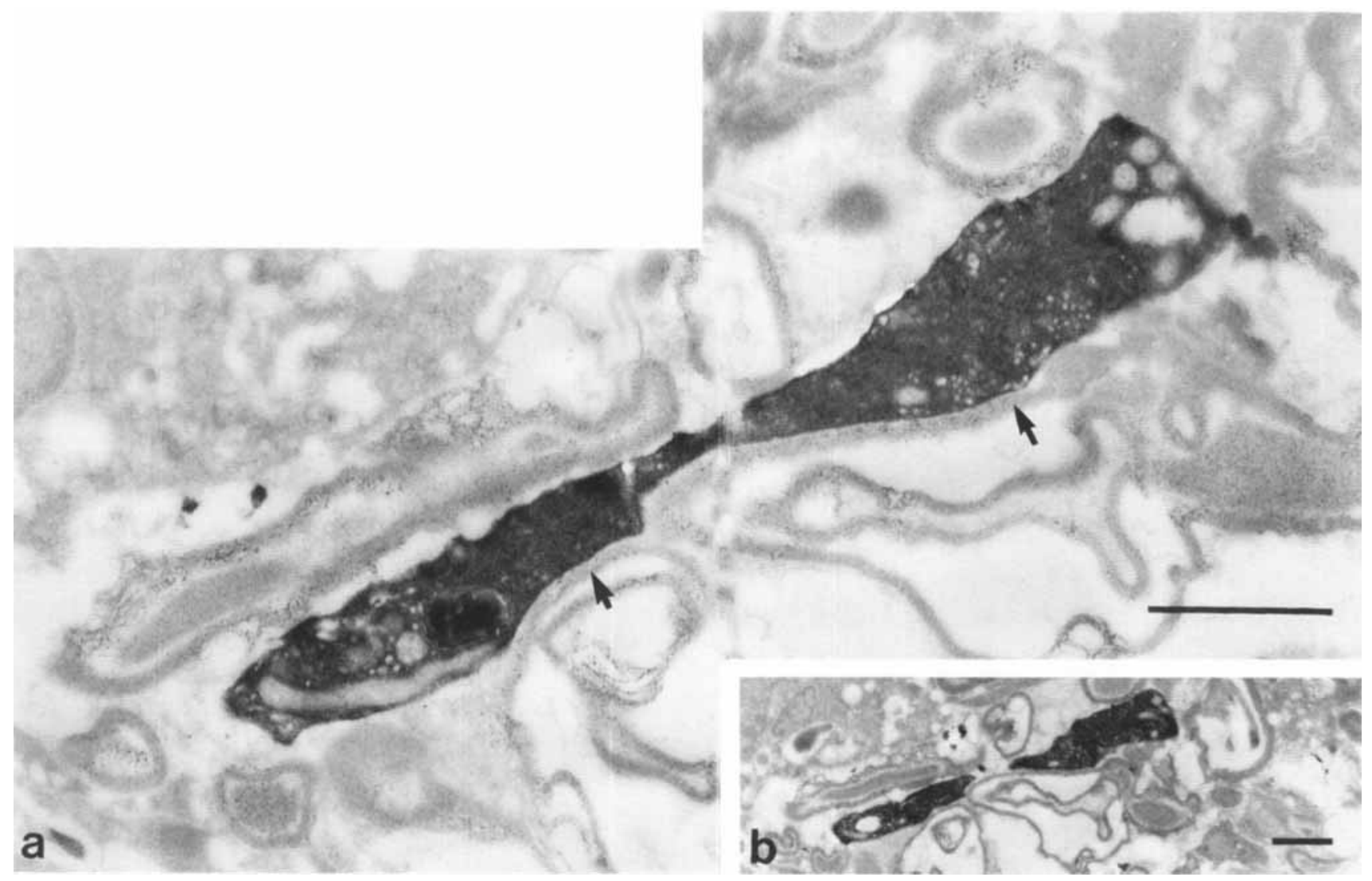

Fig. 4. The middle (a) and last (b) sections from a series of 10 ultrathin sections through an elongated, HRP-labeled growth cone lying in close association with several myelin fragments (arrows). The vesicles and tubules characteristic of growth cones are recognizable in (a). Scale bars $=1 \mu \mathrm{m}$.

contained another degenerating myelin fragment in its center. Again, the growth cones have passed, but the leading one has probably grown within and in association with the myelin fragment. We also found one axon profile in membrane-to-membrane contact with a process of a reactive astrocyte (Fig. 1b). Although the evidence is indirect, these observations support the conclusion that growth cones contact, rather indiscriminately, a wide variety of substrates.

\section{DISCUSSION}

These experiments led to the conclusion that leading regenerating growth cones contact a variety of substrates during their growth through the goldfish optic nerve. We have analyzed the elements in contact with five leading growth cones in the injured optic nerve. Growth cones were found in close association with myelin fragments. Two growth cones were seen in membrane contact with myelin only and no other cell, and two others were in contact with myelin and the surface of glial cells, one of which may be an oligodendrocyte. One bifurcated growth cone ran outside of the fascicles and touched with one branch the surface of a fibroblast-like cell and with another branch the basal lamina of the glia limitans. Growth cones may also cross other glial cells such as astrocytes. The observation of an isolated unmyelinated axon profile in contact with an astrocyte (and other structures) lends indirect support to this suggestion. Thus, during their path through the optic nerve, regenerating growth cones of the fish may perhaps quite unselectively contact a variety of nonneuronal cells and myelin fragments.

Although the sample size of identified leading growth cones is small, our study allows a significant conclusion. Four of five growth cones were seen in close association with myelin fragments. From this we conclude that fish optic nerve myelin does not inhibit axon growth in vivo. Because myelin is derived from oligodendrocytes and shares a number of proteins with their cells of origin, we may be able to extend this conclusion to these myelin-forming glial cells. Finding one growth cone in contact with a glia cell that we identified as an oligodendrocyte supports the notion that oligodendrocytes in the fish optic nerve are also growth permissive. These results are consistent with our earlier in vitro results (Bastmeyer et al., 1991) and extend them to the situation in vivo. We demonstrated in our in vitro studies that fish and mammalian retinal axons are capable of elongating on fish CNS myelin and on fish oligodendrocytes (Bastmeyer et al., 1991, 1993). Still, the outcome of our present investigation was surprising for several reasons. It has been suggested in a number of publications that regenerating retinal axons are guided by, and preferentially grow on, astrocytes (Murray, 1976; Wolburg et al., 1986) or basal lamina (Easter, 1987). Both structures are suspected of providing growth-supporting molecules, at least in the peripheral nervous system (Scherer and Easter, 1984; 

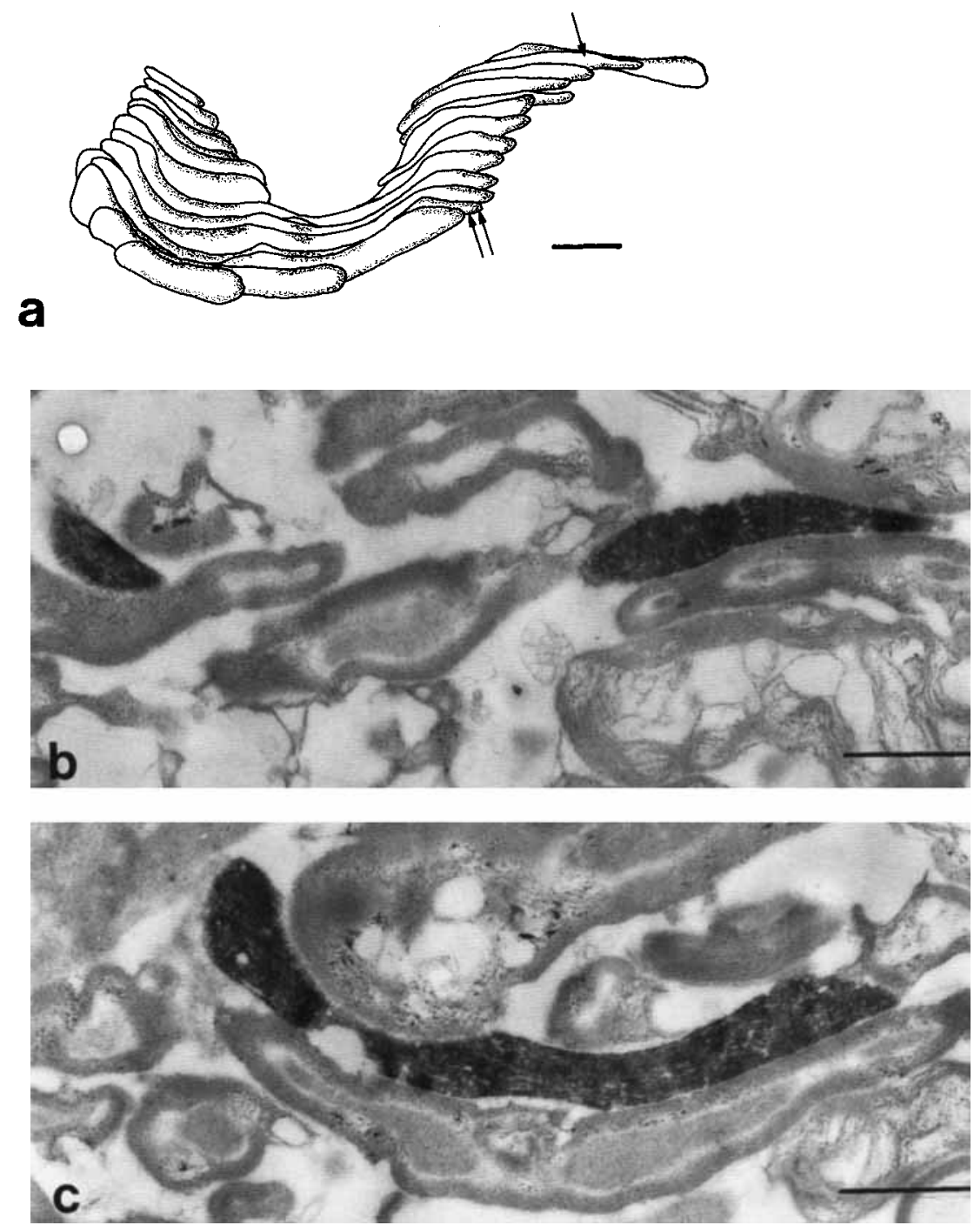

Fig. 5. Reconstruction and electron micrographs of an HRP-labeled growth cone. The arrow and double arrow in $\mathbf{a}$ indicate sections 2 and 12 , which are shown in $\mathbf{b}$ and $\mathbf{c}$, respectively. Note that the growth cone is closely associated with myelin fragments along most of its surface. Scale bars $=1 \mu \mathrm{m}$.

Reichardt and Tomaselli, 1991). Moreover, in vitro assays indicated that fish CNS myelin was not a particularly good substrate, in that the number of axons on myelin was small (Bastmeyer et al., 1991). The best in vitro substrate, judged by the impressive density of axonal outgrowth, consisted of oligodendrocytes (Bastmeyer et al., 1993). When extending on oligodendrocytes in vitro, regenerating retinal axons avoided astrocytes. We doubt that astrocytes in vivo repel growth cones because a profile of a regenerating axon was in direct contact with an astrocyte (Fig. 1b). Although we did not see the growth cone, the location of an axon is often indicative of the path the growth cone has taken. This argument also applies to the other axons, one in contact with an oligodendrocyte and the others within a degenerating myelin tube (Fig. 1a).

Furthermore, one growth cone was closely associated with the basal lamina, which probably is laid down by astrocytes and which, together with astrocyte processes, forms the glia limitans (Maggs and Scholes, 1990). However, neither astrocytes nor their basal lamina appear to be preferred by regenerating growth cones. If they were, we should have seen more instances of growth cone-astrocyte/ basal lamina contact. Unfortunately, we were not able to detect the filopodia of the growth cones in the series of ultrathin sections. It is possible that the filopodia, as a result of their exploration of the cellular environment, formed contacts with selected substrates and that the growth cone proper simply passed the surfaces described here. We cannot exclude this possibility. However, such an interpretation seems unlikely in view of the extent of the contacts of the growth cone with myelin fragments in Figures 4 and 5 and with the various cellular surfaces in Figures 3 and 6 . It appears most reasonable to propose that regenerating retinal growth cones are nonselective because they were seen in association with myelin, oligodendrocytes, and astrocyte basal lamina as well as with a fibroblastlike cell outside the boundary of the transected fascicle.

Admittedly, the sample size on which this proposition is based is small. First, the number of axons that have entered the distal (brain side) portion of the optic nerve at the 

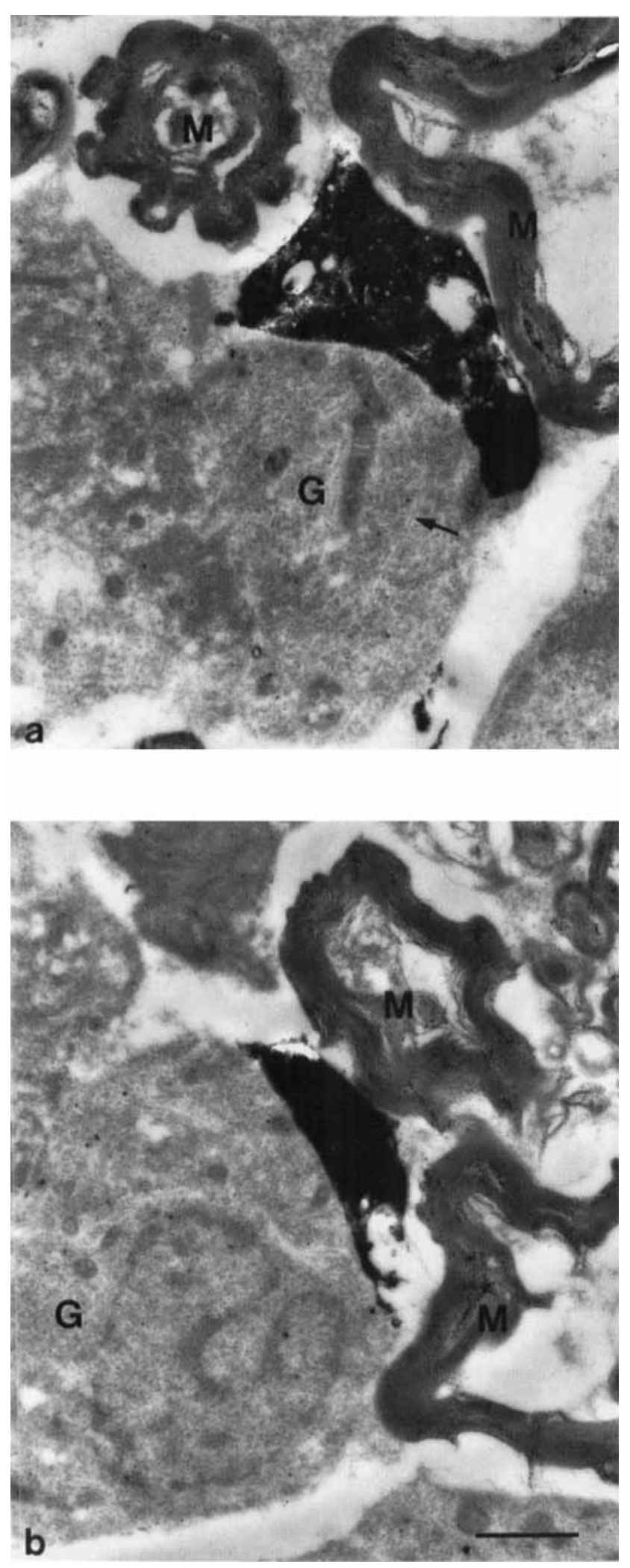

Fig. 6. a,b: Two sections (7 and 19) of an HRP-labeled growth cone whose entire extent is shown graphically in Figure 7 . The growth cone is in close contact with a glial cell (G), perhaps an oligodendrocyte, and myelin fragments $(\mathrm{M})$. Scale bar $=5 \mu \mathrm{m}$. Arrow points to microtubuli. stages investigated (9-10 days after optic nerve section) is still small. Second, the technical procedures employed to label regenerating growth cones, find them in tissue sections, reembed them, and serially section them are demanding and preclude large sample sizes. Third, in prescreening thick sections, we selected growth cones that appeared to be single and discarded those traveling along other axons. Still, five of the selected growth cones turned out to follow other axons, and they were excluded from the study. Growth cones seen on other axons, however, support one further conclusion, consistent with findings by Easter et al. (1984) and Easter (1987): The preferred substrate for growth cone elongation is apparently other axons.

The associations of growth cones with the various cells and profiles is likely to be mediated by specific molecules. Several molecular components are known that may participate in growth cone attachment to the various cells and surfaces in the optic nerve, and they shall be considered next. Teleost myelin and oligodendrocytes express two glycoproteins, IP1 and IP2 (Jeserich and Waehneldt, 1986a,b), which have sequence homologies with Po (Schliess and Stoffel, 1991). Po, a myelin protein of the mammalian PNS, belongs to the Ig superfamily of cell adhesion molecules (Williams and Barcley, 1988) and is reported to promote axon growth (Schneider-Schaulies et al., 1990). Thus, these fish myelin proteins IP1 and IP2 could potentially participate in mediating growth cone attachment to, and perhaps migration along, myelin (and perhaps oligodendrocytes) in the goldfish optic nerve.

Cultured oligodendrocytes derived from goldfish optic nerve do not carry axon growth inhibitors (Bastmeyer et al., 1991) but express the L1-like cell adhesion molecule E 587 antigen (Bastmeyer et al., 1993), which is involved in vitro in promoting growth of $\mathrm{E} 587$-positive axons along oligodendrocytes (Bastmeyer and Stuermer, unpublished results). Regenerating growth cones in the optic nerve also express $\mathrm{E}$ 587 antigen (Vielmetter et al., 1991), but whether oligodendrocytes express it in vivo has not yet been determined. Basal laminae often carry extracellular matrix proteins, and such molecules may promote axon growth along these structures (Scherer and Easter, 1984; Reichardt and Tomaselli, 1991). An instance in which retinal growth cones touched basal lamina in fish was observed in new retinal axons within the retina (Easter et al., 1984). Fibroblasts are known to produce fibronectin, and regenerating goldfish retinal axons grow on fibronectin when it is offered as a substrate in vitro (Vielmetter et al., 1990). A recent study (Hirsch et al., in press) suggests that elongated cells in the interfascicular areas are immunoreactive with antifibronectin antibodies and that these fibronectin-positive cells are the fibroblast-like cells identified in this study.

It is therefore possible that goldfish retinal growth cones in vivo accept a variety of surfaces and molecular components just as they do in vitro. They perhaps use various molecules as a substrate for their growth in vivo. This implies that regenerating axons should be equipped with sets of receptors, and some evidence for this is provided by recent findings (Battisti et al., 1992; Stuermer et al., 1992). One further possibility that may be considered is that one or several growth-promoting extracellular matrix proteins may become deposited on all profiles and in the extracellular spaces of the injured optic nerve and serve as substrate for the axons. Hopkins et al. (1985) and Battisti and colleagues (1992) reported that regenerating optic nerves not only exhibit increased laminin immunoreactivity at the 

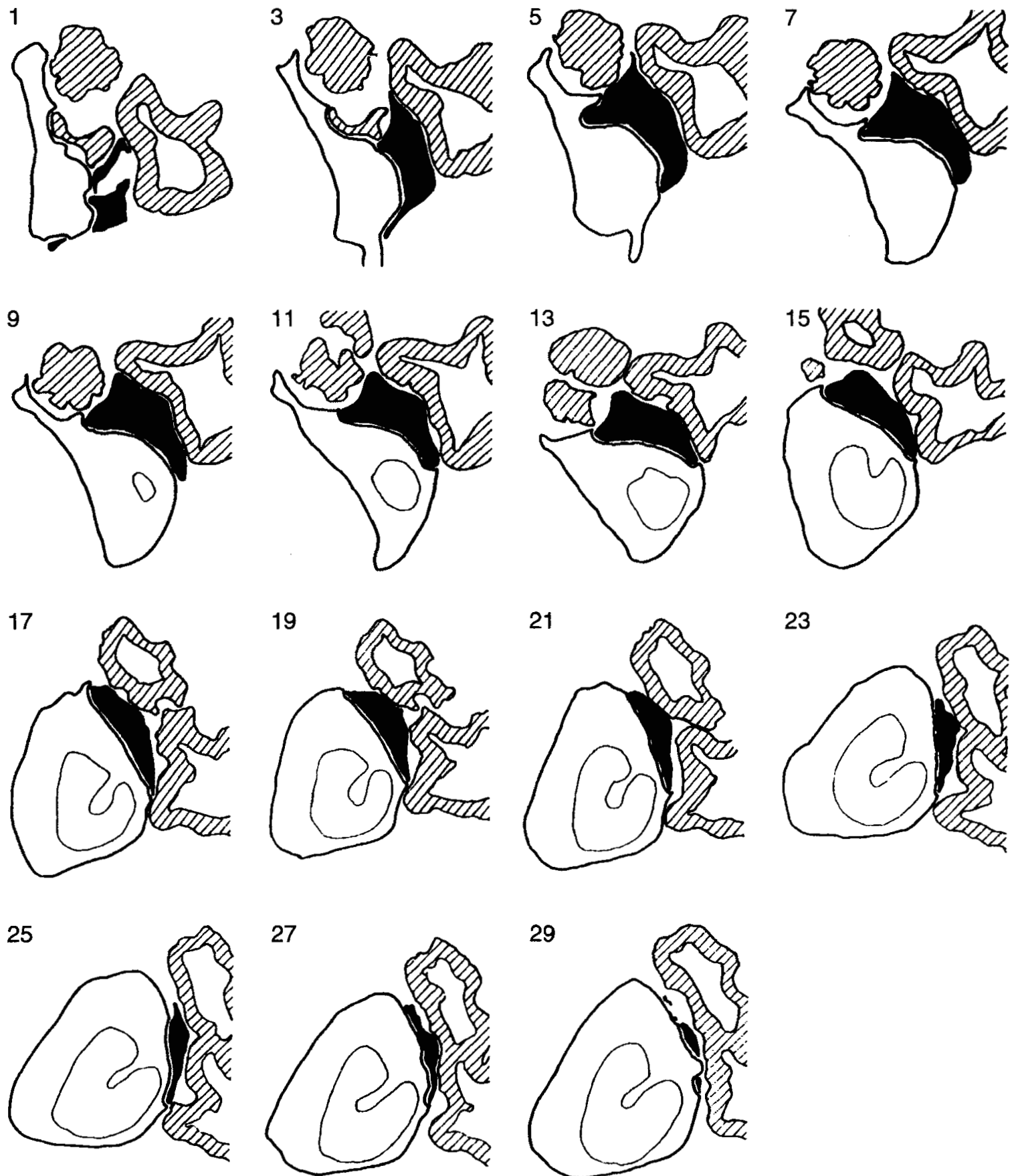

Fig. 7. Drawings of every other section of the series through the growth cone shown in Figure 6 . The growth cone is shown in black, the glial cell white, and the myelin fragments shaded. The growth cone contacts the myelin fragment most closely in sections $3-9$ and in section 27 . Scale bar $=5 \mu \mathrm{m}$.

boundaries of previous fascicles and the glia limitans but also within the fascicles. Which cells produce this growthpromoting ECM molecule and where exactly it is deposited inside the fascicles have not been postulated. Because none of the antibodies against laminin that we tested binds to goldfish nervous system, we were unsuccessful in resolving this issue.

Nona et al. (1992) reported that Schwann cells invade the optic nerve when the nerve is crushed and may, due to their favorable substrate properties, assist the regrowth of axons. In collaboration with Samual Nona, we were able to exclude the possibility that Schwann cells invade and populate the optic nerve when the nerve is cut instead of crushed (Bastmeyer and Nona, unpublished results). Thus, in the case of optic nerve cut, Schwann cells do not play a decisive role for goldfish retinal axon regeneration.

The preferred substrate for regenerating growth cones is undoubtedly other retinal axons. For their growth along 


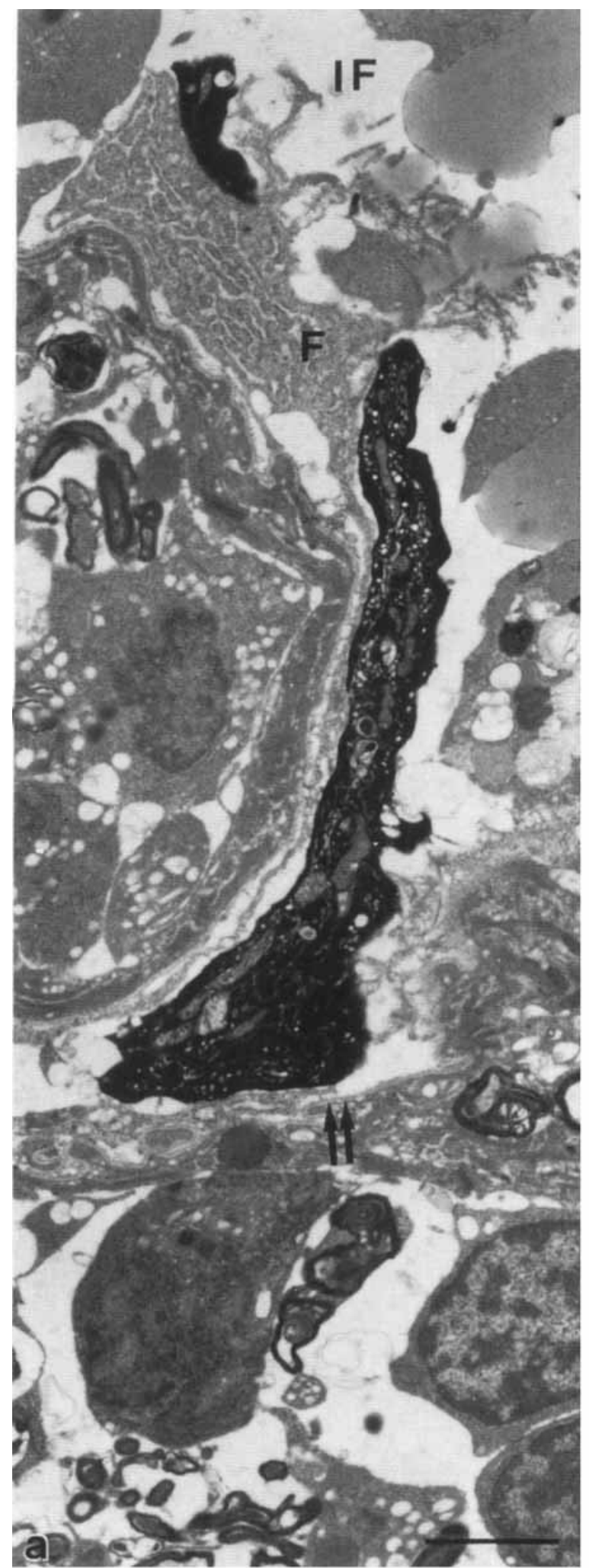

Fig. 8. Two representative sections (33 and 14) of a serially sectioned HRP-labeled growth cone, located outside the boundaries of previous fascicles in the interfascicular area (IF). a: The growth cone contacts a fibroblast-like cell $(\mathbf{F})$ and either a cellular process or the

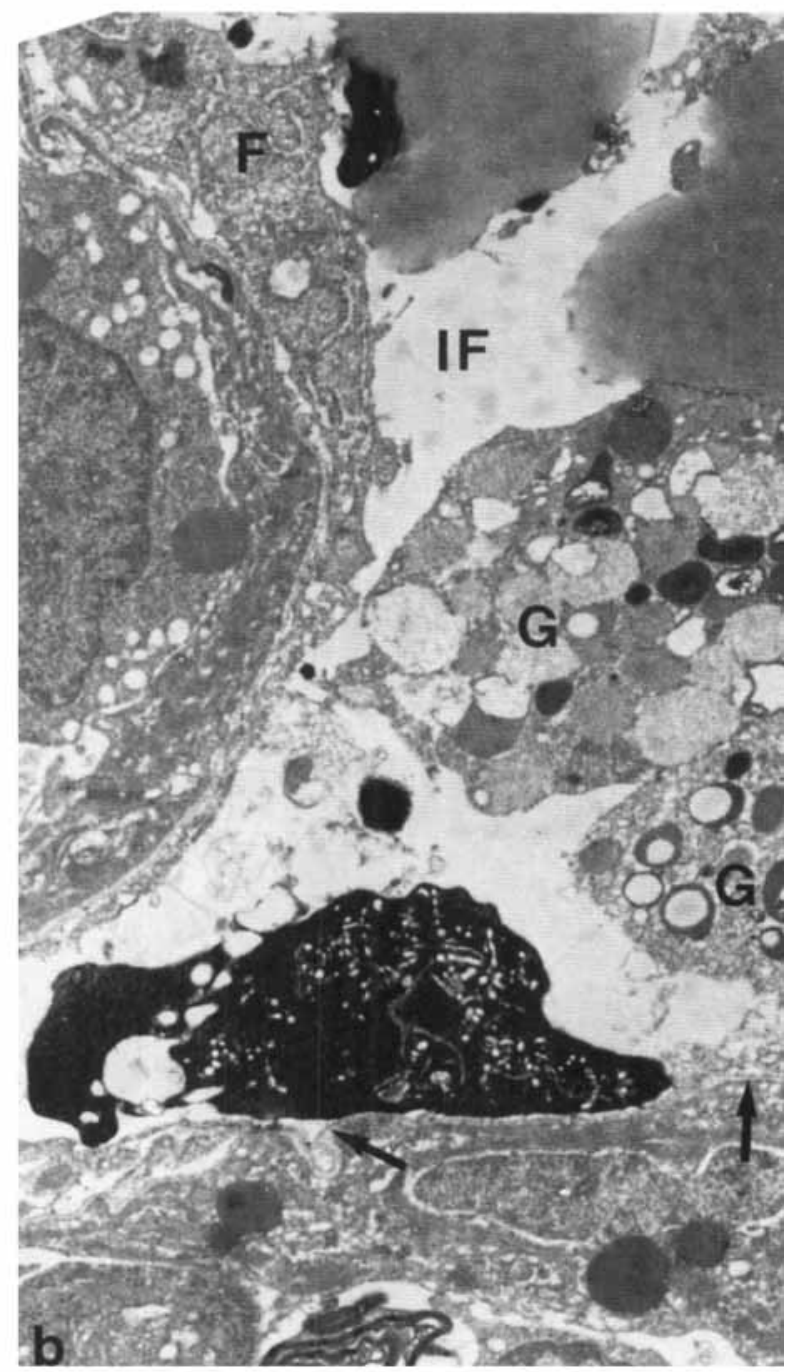

basal lamina, which is clearly distinguishable (double arrows) on a nearby cell. b: The growth cone contacts basal lamina (arrows) associated with an astrocyte process (arrows). Granulocytes (G) are present in the interfascicular area (IF). Scale bar $=2 \mu \mathrm{m}$. 

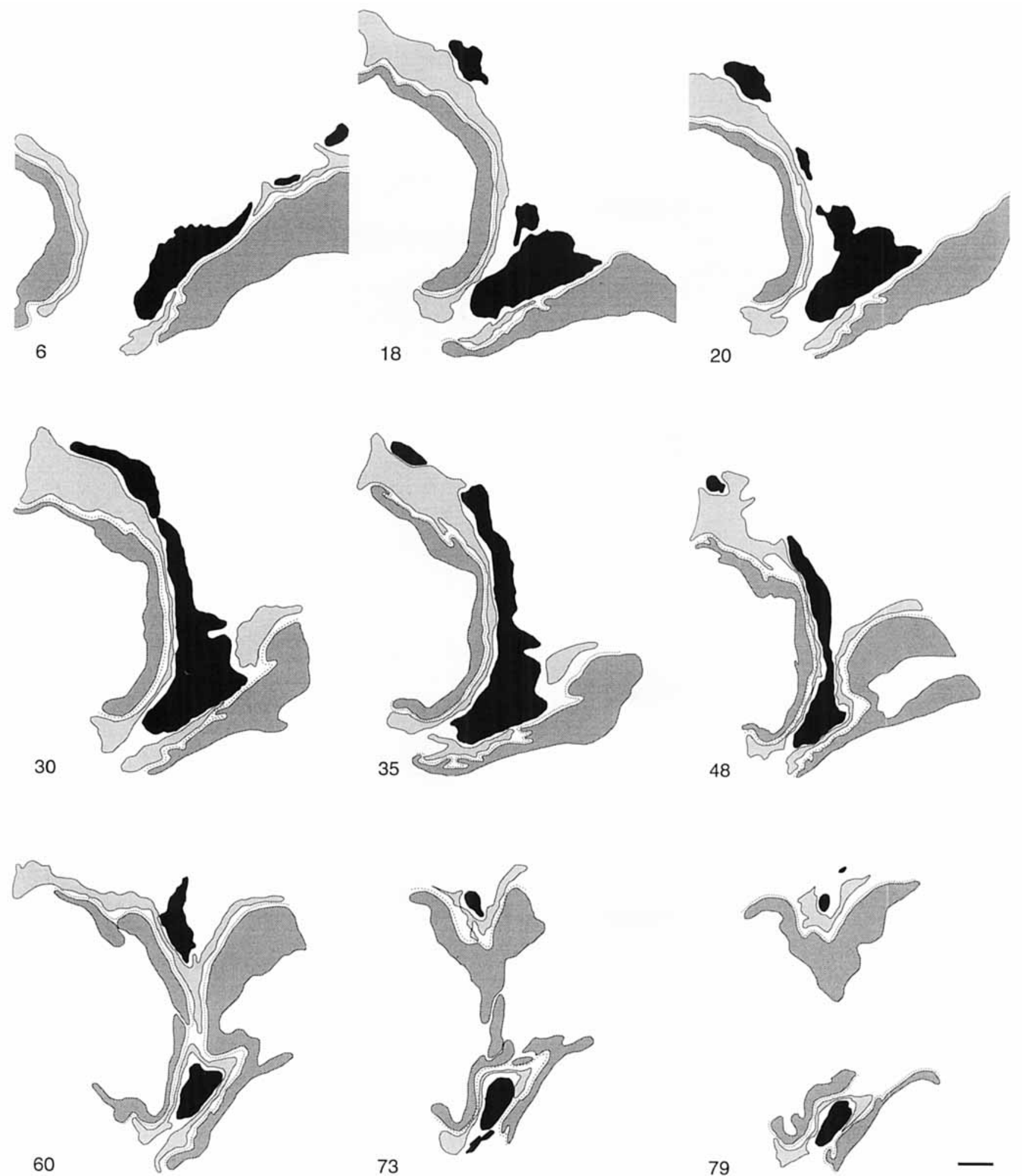

Fig. 9. Graphic representation of the bifurcated growth cone shown in Figure 8. The numbers indicate the sections of the series. The growth cone is shown in black, the fibroblast light gray, the astrocytes darker

gray, and the basal lamina as a dotted line. It is apparent that the fibroblast maintains proximity to the growth cone in most of the sections. Scale bar $=2 \mu \mathrm{m}$.

other axons, growth cones have a number of cell surface molecules available (Battisti et al., 1992; Stuermer et al., 1992). Using specific antibodies, we have identified four molecules, three of which are cell adhesion molecules that are reexpressed when retinal axons regenerate (Wehner and Stuermer, 1989; Bastmeyer et al., 1990; Vielmetter et 
al., 1991; Paschke et al., 1992). These probably mediate growth cone elongation along preexisting axons, which has in fact been verified in in vitro assays for one of these molecules (Giordano et al., 1993).

A question that remains to be answered is how injured axons manage to cross the gap created by transecting the optic nerve. In injured fiber tracts in the CNS of mammals, astrocytes are known to respond quickly. They form the glial scar that partly seals the proximal nerve stump. Astrocytes in fish will obviously not form such a barrier. An extended investigation of the cellular response in the fish optic nerve upon transection will help us to understand better the kind of cellular environment that may be optimal for successful regeneration of injured axons in the vertebrate CNS.

\section{ACKNOWLEDGMENTS}

The authors thank their colleagues John Scholes for helping with the identification of the glial cells and for extensive advice, Roland Hengstenberg for introducing one of us (G.S.) to the computer-aided reconstruction of serial sections, Florian Rauschenbach for his expertise in producing one of the graphics, and Heinz Schwarz for help with electron microscopy. We also thank Mary Anne Cahill for help with the layout and for corrections to the manuscript, Suzanne Giordano for helpful comments on the manuscript, and Doris Bliestle for the photographs. This work was supported by grants from the Deutsche Forschungsgemeinschaft, the Gemeinnützige Hertiestiftung, and the ARC Programm of the Deutscher Akademischer Austauschdienst.

\section{LITERATURE CITED}

Attardi, D.G., and R.W. Sperry (1963) Preferential selection of central pathways by regenerating optic fibres. Exp. Neurol. 7:46-64.

Bastmeyer, M., B. Schlosshauer, and C.A.O Stuermer (1990) The spatiotemporal pattern of N-CAM in the retinotectal pathway of adult goldfish detected by the monoclonal antibody D3. Development 108:299-31.

Bastmeyer, M., M. Beckmann, M.E. Schwab, and C.A.O. Stuermer (1991) Growth of goldfish regenerating axons is inhibited by rat oligodendro* cytes and CNS myelin but not by goldfish optic nerve/tract oligadendrocytes and fish CNS myelin. J. Neurosci. 11:626-640.

Bastmeyer, M., M. Bähr, and C.A.O. Stuermer (1993) Fish optic nerve oligodendrocytes support axonal regeneration of fish and mammalian retinal ganglion cells. Glia 8:1-11.

Battisti, W.P., Y. Shinar, M. Schwartz, P. Levitt, and M. Murray (1992) Temporal and spatial patterns of expression of laminin chondroitin sulphate proteoglycan and HNK-1 immunoreactivity during regeneration in the goldfish optic nerve. J. Neurocytol. 21:557-573.

Bovolenta, P., F. Wandosell, and M. Nieto-Sampedro (1991) Central neurite outgrowth over glial scar tissue in vitro. In P.C. Letourneau, S.B. Kater, and E.R. Macagno (eds): The Nerve Growth Cone. New York: Raven Press, pp. 477-488

Caroni, P., and M.E. Schwab (1988) Two membrane protein fractions from rat central myelin with inhibitory properties for neurite growth and fibroblast spreading. J. Cell Biol. 106:1281-1288.

Easter, S.S. (1987) Retinal axons and the basal lamina. In J.R. Wolf, J. Sieuers, and M. Berry (eds): Mesenchymal-Epithelial Interactions in Neural Development. NATO ASI Series, Vol. H5. Berlin: SpringerVerlag, pp. 385-396.

Easter, S.S., A.C. Rusoff, and P.E. Kish (1981) The growth and organization of the optic nerve and tract in juvenile and adult goldfish. J. Neurosci $8: 793-811$.

Easter, S.S., B. Bratton, and S.S. Scherer (1984) Growth-related order of the retinal fiber layer in goldfish. J. Neurosci. 4:2173-2190.

Fawcett, J.W., J. Rokos, and I. Bakst (1989) Oligodendrocytes repel axons and cause axonal growth cone collapse. J. Cell Sci. 92:93-100.
Fulcrand, J., and A. Privat (1977) Neuroglial reactions secondary to wallerian degeneration in the optic nerve of the postnatal rat: Ultrastructural and quantitative study. J. Comp. Neurol. 176:189-224.

Giordano, S., M. Bastmeyer, A.Y. Loos, and C.A.O. Stuermer (1993) Expression of $\mathbf{E} 587$ antigen in embryonic zebrafish CNS and in vitro functional analysis. Soc. Neurosci. Abstr. 19:1090.

Hengstenberg, R., H. Bülthoff, and B. Hengstenberg (1983) Threedimensional reconstruction and stereoscopic display of neurons in the fly visual system. In N.J. Strausfeld (ed): Functional Neuroanatomy. Berlin: Springer, pp. 183-185.

Hirsch, S., M.A. Cahill, and C.A.O. Stuermer (1994) Fibroblasts repopulate the lesion after transection of goldfish optic nerves and are permissive substrates for regenerating axons. Proceedings of the 22nd German Neurobiology Meeting. Stuttgart: Thieme Verlag, in press.

Hopkins, J.M., T.S. Ford-Holevinski, J.P. McCoy, and B.W. Agranoff (1985) Laminin and optic nerve regeneration in the goldfish. J. Neurosci 5:3030-3038.

Jeserich, G., and T.V. Waehneldt (1986a) Characterization of antibodies against major fish CNS myelin proteins: Immunoblot analysis and immunohistochemical localization of $36 \mathrm{~K}$ and IP2 proteins in trout nerve tissue. J. Neurosci. Res. 15:147-158.

Jeserich, G., and T.V. Waehneldt (1986b) Bony fish myelin: Evidence for common major structural glycoproteins in central and peripheral myelin of trout. J. Neurochem. 46:525-533.

Keirstead, H.S., Hasan, S.J., Muir, G.D., and J.D. Steeves (1992) Suppression of the onset of myelination extends the permissive period for the functional repair of embryonic spinal cord. Proc. Natl. Acad. Sci. USA 89:11664-11668

Lanners, H.N., and B. Grafstein (1980) Early stages of axonal regeneration in the goldfish optic tract: An electron microscopic study. J. Neurocytol 9:733-751.

Letourneau, P.C., S.B. Kater, and E.R. Macagno (1991) The Nerve Growth Cone. New York: Raven Press.

Luizzi, F.J., and R.J. Lasek (1987) Astrocytes block axonal regeneration in mammals by activating the physiological stop pathway. Science $237: 642-$ 645.

Maggs, A., and J. Scholes (1990) Reticular astrocytes in the fish optic nerve: Macroglia with epithelial characteristics form an axially repeated lacework pattern, to which nodes of ranvier are apposed. J. Neurosci. 10:1600-1614.

Mori, S., and C.P. Leblond (1970) Electron microscopic identification of three classes of oligodendrocytes and a preliminary study of their proliferative activity in the corpus callosum of young rats. J. Comp. Neurol. 139:1-30.

Murray, M. (1976) Regeneration of retinal axons into the goldfish optic tectum. J. Comp. Neurol. 168:175-196.

Nona, S.N., A. Duncan, C.A. Stafford, A. Maggs, G. Jeserich, and J.R. Cronly-Dillon (1992) Myelination of regenerated axons in goldfish optic nerve by Schwann cells. J. Neurocytol. 21:391-401.

Paschke, K.A., F. Lottspeich, and C.A.O. Stuermer (1992) Neurolin, a cell surface glycoprotein on growing retinal axons in the goldfish visual system is reexpressed during retinal axonal regeneration. J. Cell Biol. 117:863-875.

Peters, A., S.L. Palay, and H.D.E.F. Webster, Eds. (1991) The Fine Structure of the Nervous System. New York: Oxford University Press.

Reichardt, L.F., and K.J. Tomaselli (1991) Extracellular matrix molecules and their receptors: Functions in neural development. Annu. Rev. Neurosci. 14:531-70.

Rhodin, J.A.G., Ed. (1977) Histology. New York: Oxford University Press.

Scherer, S.S., and S.S. Easter (1984) Degenerative and regenerative changes in the trochlear nerve of goldfish. J. Neurocytol. 13:519-565.

Schliess, F., and W. Stoffel (1991) Evolution of the myelin integral membrane proteins of the central nervous system. Biol. Chem. Hoppe-Selyer $372: 865-874$.

Schneider-Schaulies, J., A. von Brunn, and M. Schachner (1990) Recombined peripheral myelin protein Po confers both adhesion and neurite outgrowth-promoting properties. J. Neurosci. Res. 27:286-297.

Schwab, M.E., and P. Caroni (1988) Oligodendrocytes and CNS myelin are nonpermissive substrates for neurite growth and fibroblast spreading. J. Neurosci. 8:2381-2393.

Skene, J.H.P. (1989) Axonal growth-associated proteins. Annu. Rev. Neurosci. 12:127-156.

Stafford, C.A., S.A.S. Shehab, S.N. Nona, and J.R. Cronly-Dillon (1990) Expression of glial fibrillary acidic protein (GFAP) in goldfish optic nerve following injury. Glia 3:33-42. 
Strobel, G., and C.A.O. Stuermer (1991) Substrates for regenerating goldfish retinal axons in vivo. Soc. Neurosci. Abstr. 17:211.

Stuermer, C.A.O. (1988a) Trajectories of regenerating retinal axons in the goldfish tectum: I. A comparison of normal and regenerated axons at late regeneration stages. J Comp. Neurol. 267:55-68.

Stuermer, C.A.O. (1988b) Trajectories of regenerating retinal axons in the goldfish tectum: II. Exploratory branches and growth cones on axons at early regeneration stages. J. Comp. Neurol 267:69-91.

Stuermer, C.A.O., M. Bastmeyer, M. Bähr, G. Strobel, and K. Paschke (1992) Trying to understand axonal regeneration in the CNS of fish. J. Neurobiol. 23:537-550

Vaughn, J.E., and D.C. Pease (1970) Electron microscopic studies of wallerian degeneration in rat optic nerves. II. Astrocytes, oligodendrocytes and adventitial cells. J. Comp. Neurol. 140:207-226.

Venable, J.H., and R. Coggeshall (1965) A simplified lead citrate stain for use in electron microscopy. J. Cell Biol. 25:407-440.
Vielmetter, J., B. Stolze, F. Bonhoeffer, and C.A.O. Stuermer (1990) In vivo assay to test differential substrate affinities of growing axons and migratory cells. Exp. Brain Res. 81:283-287.

Vielmetter, J., F. Lottspeich, and C.A.O. Stuermer (1991) The monoclonal antibody $\mathrm{E} 587$ recognizes growing (new and regenerating) retinal axons in the goldfish retinotectal pathway. J. Neurosci. 11:3581-3593.

Wehner, K., and C.A.O. Stuermer (1989) Monoclonal antibody M802 recognizes regenerating retinal axons in goldfish. Soc. Neurosci. Abstr. 15:1027.

Williams, A.F., and A.N. Barcley (1988) The immunoglobulin superfamily domains for cell surface recognition. Annu. Rev. Immunol. 6:381-405.

Wolburg, H., and R. Kästner (1984) Astroglial-axonal interrelationship during regeneration of the optic nerve in goldfish. A freeze-fracture study. J. Hirnforsch. 25:493-504.

Wolburg, H., J. Neuhaus, and A. Mack (1986) The glio-axonal interaction and the problem of regeneration of axons in the central nervous system-Concepts and perspectives. Z. Naturforsch. 41c:1147-1155. 